\title{
EXCHANGE RATE PASS-THROUGH IN MOROCCO: A STRUCTURAL VAR APPROACH
}

\author{
El Amri Younessi, \\ Abdelhamid El Bouhadi, \\ Mimoun Benali \\ National School of Commerce \\ and Management, \\ University of Fez, \\ Morocco
}

\begin{abstract}
:
This study analyzes the impact of short- and long-term exchange rate fluctuations in Morocco. The purpose of this paper is to study the shocks transmission of exchange rates variations to prices index known as exchange rate pass-through. The empirical results of the quarterly data between 2000 and 2018 revealed that the pass-through of the exchange rate in Morocco is quite important, but incomplete and delayed in three categories of price index: consumer price index, Imports price Index and Industrial production price Index.
\end{abstract}

JEL: G15, G17, C51, C52

Keywords: pass-through; inflation; REER; SVAR model; Morocco

\section{Introduction}

Exchange rate pass-through represents the percentage of variance in domestic price changes attributed to a certain percentage related to exchange rate fluctuations. Ca'Zorzi et al. (2007) and Aliyu et al. (2009) confirmed that exchange rate pass-through is higher in developing and emerging countries than in developed countries. However, some famous empirical studies have found the opposite, Frankel et al. (2005) fund that it is important to measure the response of domestic prices to the nominal exchange rate, due to its important implications for monetary policy.

The degree of adjustment of domestic prices to exchange rate fluctuations is essential to understand inflation dynamics and therefore to guide the monetary policy; the pass-through of exchange rate to inflation varies across countries and over time. The

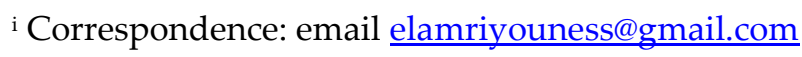


impact of exchange rate changes on domestic price index, especially consumer price index depends on openness, inflation and credibility of monetary policy.

It is generally accepted that the move toward more credible monetary policy plays an important role in reducing the ERPT to domestic prices. Taylor (2000) was the first who supports this perspective and put forward the hypothesis that an environment of low and stable inflation leads to a low ERPT to domestic prices. He showed that lower pass-through is due to a lower perceived persistence of price and cost changes, which tends to be reduced in an environment where inflation is low and monetary policy is more credible.

The consequences of variations of exchange rate on inflation depend on many factors, the main factor which retains the attention of investors and rating agencies for sovereign state risk is that inflation ultimately depends on monetary policy. An inflation targeting monetary policy does not allow exchange rate changes to degenerate into inflationary trends.

To discuss the inconvenience of a high pass-through, it is important to focus on the negative impacts of a rise in domestic prices, which is translated into a rise in inflation and reducing in the value of money that erodes its purchasing power. It is also generally associated with higher interest rates; it can even produce low savings and discourages investment and long-term growth. Moreover, it can also erode exports competitiveness and leads ultimately to a balance of payments deficit.

Companies are not exempt from high exchange rate disturbances; a change in exchange rates will affect production costs as well as the prices of imported goods. The transmission of exchange rate shocks to producer prices weakens the competitiveness of domestic goods in international markets.

Considering the high degree of openness of Moroccan economy, the country established several policies, particularly monetary ones to ensure macroeconomic stability and to successfully integrate the country into the international economy. In this context, the central bank of Morocco has judged necessary to prepare for the adoption of a policy targeting inflation in addition to the transition to a more flexible exchange rate regime.

As a result, a study on the estimation of the degree of pass-through of exchange rate shocks to domestic prices is required in order to assess and analyze the response of prices to an exchange rate change. This will also allow the central bank of Morocco to anticipate the results of the transition to a more flexible exchange rate regime.

The exchange rate channel appears to be an important role as a transmission mechanism for monetary policy, especially that a new exchange rate policy had been initiated. This policy is based on a gradual bifurcation towards a floating exchange rate since 2015 and a monetary policy based on inflation targeting.

In Morocco, the lack of studies carried out about the impact of the exchange rate on domestic prices makes the economic impact of higher pass-through more ambiguous.

This paper aims to give a suitable measure of magnitude of exchange rate fluctuations and its impact on inflation in Morocco and it can be considered as a contribution in the field of scientific research to test and measure the exchange rate 
change pass-through on Moroccan domestic prices during the period of 2000-2018 with a quarterly data.

While the most empirical studies have examined the "pass-through" effect of the exchange rate in Morocco using a VAR model, this current study uses a structural vector autoregressive model (SVAR). Recent empirical studies have preferred to use SVAR models because the VAR models have been criticized for being deprived of any economic content. The SVAR models are used to examine the response of variables to structural shocks. They provide historical decomposition that measures cumulative contribution of each structural shock in each variable over time.

This paper attempts to estimate the ERPT to the import, producer and consumer price shocks in Morocco from 2000Q1 to 2018Q4 by using SVAR model and highlighting structural shocks (shocks of supply, demand, monetary policy and exchange rate).

\section{Literature review}

The complexity of understanding the ERPT, as well as the devaluation of the national currency is certainly an interesting topic for academics, policy makers, and practitioners over the past few decades. The ERPT to domestic prices was studied using a wide range of domestic price index ranging from the import price index (MPI) to the consumer price index $(\mathrm{CPI})$, the industrial producer price index (PPI), and even the export price index (EPI) using a variety of data.

Theoretical studies have provided a better understanding of the influence of the ERPT on domestic prices.

The controversial relationship between exchange rate variations and inflation described by the pass-through phenomenon has been analyzed and discussed by several authors who are especially interested in macroeconomics. Dornbuch (1976) sees that the exchange rate-inflation relationship is vitally important, especially in emerging economies. In these economies, exchange rate fluctuations can significantly affect the general level of prices. In the economic literature, the transmission mechanisms of exchange rates to prices are generally defined through two channels, direct and indirect: Hendry (1980) sees that the direct channel is associated with the concept of the law of one price and purchasing power parity. Consequently, the impact of changes in the exchange rate to price of imported goods is directly reflected in the domestic prices. The indirect channel is expressed as a channel of total demand. The increase in the exchange rate leads to a lower price of domestic products for foreign consumers, which induces an increased export and a highest total demand and price. The increase in the price of foreign currency increases the rate of inflation, the indirect channel of exchange rate transmission relates to the competitiveness of goods in the international markets. The indirect channel of transmission has two alternatives; one alternative occurs if locally produced goods are primarily production inputs. In this case, producer price levels are expected to rise and, as a result, consumer price levels are expected to increase. The other alternative occurs if the locally produced goods are finished products. As a result, local producers and 
retailers may increase their selling prices in response to price increases from foreign competitors in order to maintain their profit margins.

The literature shows that the exchange rate shock effectively influences the domestic price of imports. This shock is transmitted to producer prices and then to consumer prices. McCarthy (2000), Soto and Selaive (2003) and Takhtamanova (2008) identified the degree of openness as an influential factor in the exchange rate changes. All of these authors argued that greater the degree of openness, the larger is the passthrough. Krugman (1989), Darvas (2001), Steel and King (2004), Beirne and Bijsterbosch (2009) and Razafimahefa (2012), all of the authors argued that the exchange rate regime is another key factor that could affect the pass-through of the exchange rate to domestic prices. In fixed regimes, economic agents consider that a change in the exchange rate is permanent and will have a permanent impact on their production costs. Consequently, they quickly adjust selling prices. On the other hand, in flexible regimes, economic agents consider exchange rate changes to be temporary.

About reducing the pass-through effect, some authors like Coulibaly and Kempf (2010) suggest that inflation targeting in emerging countries has contributed to reduce the pass-through to different price index and the contribution of exchange rate shocks to prices fluctuations decreases after the adoption of inflation targeting strategy.

The link between inflation and ERPT has been studied empirically in detail in literature, Choudhri and Hakura (2006) found strong evidence of a positive and significant association between pass-through and inflation using a panel of 71 countries for the period of 1979-2000.

Since the 2000s, studies have focused on the macroeconomic factors that influence the degree of EPRT to consumer prices. Common macroeconomic determinants of ERPT mentioned in many studies have included the level of inflation and its volatility, the trade openness, the output-gap and the exchange rate regimes. Gagnon and Ihrig (2004), Ghosh and Rajan (2009). For example, Taylor (2000) inferred that the ERPT is low in countries with low inflation level.

Adopting an innovative approach like SVAR model to examine the traditional issue of ERPT is worth considering for robust results, Forbes et al (2018) estimated the implicit ERPT for prices for different shocks and found that the ERPT is low following demand shocks and higher following monetary shocks. Hajek and Horvath (2016) have shown that the Czech Republic has an average pass-through about 20 percent of exchange rate movements on the CPI over the period 1998-2013 and that the ERPT varies according to the different specifications of the SVAR framework model. In Asia, the SVAR framework has been adopted to quantify the degree of ERPT relative to domestic prices. For the case of China, Jiang and Kim (2013) found that there is a rapid and incomplete pass-through from exchange rate fluctuations to domestic prices using the PPI (production price index) and RPI as (retail price index). The authors found also that the magnitude of the ERPT to the PPI is much higher than of the RPI in the short term $(0.27$ and 0.11 respectively), and the same impact for the medium term (1.02 and 0.62 respectively). A very large study recently done by Vo et al. (2018) in five members of ASEAN region including Indonesia, Malaysia, the Philippines, Thailand and Singapore 
which focused on the discussion of an incomplete pass-through to MPI, PPI and CPI. Indonesia has experienced the highest ERPT relative to producer and consumer prices (about 0.6 and 0.5 respectively), while four other countries recorded low ERPTs relative to the domestic prices. The results indicate that the size and speed of the ERPT varies considerably from one empirical context of studies to another depending on country specific characteristics and timeframe.

A lot of authors argued that the increased international trade greatly increases the pass-through phenomenon, but some others consider that interdependence among countries through trade linkage declines the level of pass-through. Benigno and Faia (2016) see that the increased trade integration resulting from globalization forces exporters to be more responsive to the prices set by their competitors and, therefore, the mark-up is optimized for exchange rate changes Gust et al (2010).

In Moroccan context, the majorities of studies that have been done on the relationship between the exchange rate and inflation has not given importance to the pass-through as an macroeconomic phenomenon and have focused on the reaction of domestic prices to exchange rate fluctuations without analyzing the pass-through to producer prices and import prices index. The empirical study carried out by Rachidi and Asandadi (2016) has been examined the reaction of domestic prices to exchange rate changes using VAR model found that any real shock to exchange rate led to a significant reaction of inflation, and that this reaction seems reflecting a low and modest degree of pass-through.

However, the issue of ERPT to prices, in general CPI (consumption price index), PPI (production price index) and MPI (Imports price index) has been largely ignored in the Moroccan context, particularly during the recent periods following the global financial crisis. The current study therefore attempts to overcome this lack by using an innovative approach which will allow estimating the degree of exchange rate passthrough.

The (SVAR) modeling is used in order to analyze the effects of the exchange rate on the industrial production index, on the consumer and import price indices.

\section{Material and Methods}

In order to apprehend the Moroccan macroeconomic environment and provide the appropriate context for examining the pass-through of exchange rate. A multivariate methodology of Structural Vector Autoregressive (SVAR) is used to analyze the shortterm dynamic effects of exchange rate on prices.

SVAR models also use the restrictions imposed by economic theory to identify the system, i.e. starting from a reduced form of shocks to obtain an impulse response functions with an economic interpretation.

The SVAR model includes five variables. Three Price indices and the real effective exchange rate are the main variables of interest, for estimating and analyzing the response of prices to exchange rate shocks. The basic model uses the real effective exchange rate (REER). The imports price index (MPI) is also included to determine the 
main transmission channel of the exchange rate in Morocco. In addition, the inflation rate is represented by two price indices, the industrial production price index represented by (IPI) and the consumer price index (CPI). The data are presented in Table 1 below (variables description).

Table 1: Variables' description

\begin{tabular}{|l|l|l|}
\hline Variables & \multicolumn{1}{|c|}{ Description } & \multicolumn{1}{c|}{ Variable type } \\
\hline REER & $\begin{array}{l}\text { Real effective } \\
\text { exchange rate }\end{array}$ & $\begin{array}{l}\text { Exogenous variable (shocks related to an excessive } \\
\text { demand of money) }\end{array}$ \\
\hline MPIii & $\begin{array}{l}\text { Imports price } \\
\text { index }\end{array}$ & $\begin{array}{l}\text { Endogenous variable (shocks related to a disruption } \\
\text { of demand or exchange rates of goods) }\end{array}$ \\
\hline CPI & $\begin{array}{l}\text { Consumer price } \\
\text { index }\end{array}$ & $\begin{array}{l}\text { Endogenous variable (shocks related to a demand } \\
\text { instability, or variations in the prices of goods) }\end{array}$ \\
\hline M & Money supply & Endogenous variable (money supply shock) \\
\hline PPI & $\begin{array}{l}\text { Industrial production } \\
\text { price index }\end{array}$ & $\begin{array}{l}\text { Endogenous variable (shocks related to disturbance in } \\
\text { production activity / supply) }\end{array}$ \\
\hline
\end{tabular}

\section{Data description and analysis}

\subsection{Descriptive statistics}

The result shown in Table 2 below refers to the descriptive statistics of the different variables. The series (LREER, LCPI, and LIPI) show asymmetry more or less compared to the normal distribution. These series are platykurtic, the hypothesis of the normality of the series is rejected by the Jarque-Berra test. For the other series (LMPI, LMS), the hypothesis of normality seems to be accepted.

Table 2: Descriptive statistics

\begin{tabular}{|l|c|c|c|c|c|}
\hline Variables & LREER & LMPI & LCPI & LMS & LIPI \\
\hline Mean & 4.617969 & 3.180722 & 6.575138 & 13.50812 & 4.579340 \\
\hline Mednia & 4.620588 & 3.279716 & 6.592428 & 13.66069 & 4.595624 \\
\hline Maximum & 4.707768 & 5.661918 & 6.702697 & 14.09362 & 4.799914 \\
\hline Minimum & 4.548848 & 2.272126 & 6.420646 & 12.75367 & 4.307168 \\
\hline Std. Dev. & 0.038917 & 0.578476 & 0.084508 & 0.436218 & 0.119430 \\
\hline Skewness & 0.134406 & 1.214451 & -0295381 & -0.470785 & -0.451816 \\
\hline Kurtosis & 1.933974 & 7.429429 & 1.805247 & 1.797779 & 2.401315 \\
\hline Jarque-Bera & 3.626015 & 76.55822 & 5.329303 & 6.995675 & 3.524918 \\
\hline Probability & 0.163163 & 0.000000 & 0.069624 & 0.030263 & 0.171622 \\
\hline Sum & 332.4938 & 229.0120 & 473.4100 & 972.5844 & 329.7124 \\
\hline Sum Sq. Dev. & 0.107531 & 23.75903 & 0.507053 & 13.51031 & 1.012710 \\
\hline Observations & 72 & 72 & 72 & 72 & 72 \\
\hline
\end{tabular}

\subsection{Graphic representation of the series}

By this informal test (graphic visualization in Figure 1, below), it is assumed the nonstationarity of variables (in variance for "LREER, LMPI"), and in mean for the others.

ii We use the importations values as a proxy of MPI because data of importations index are not available. 


\section{REER}

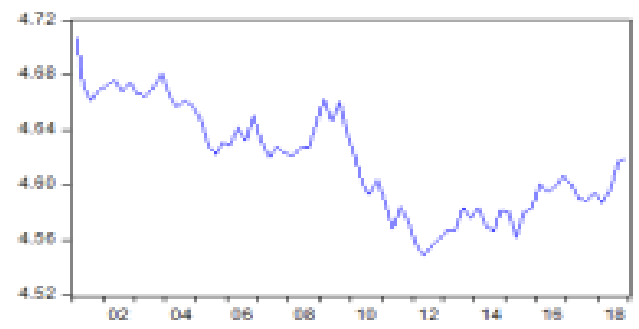

LPCI

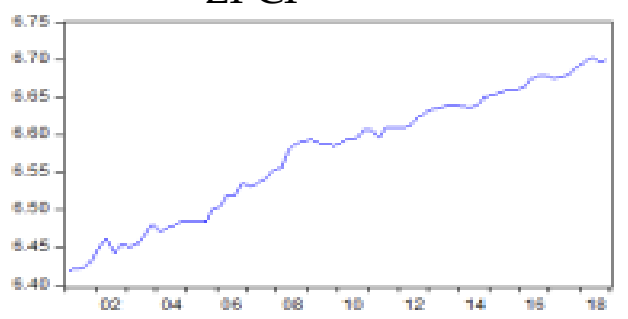

LMPI

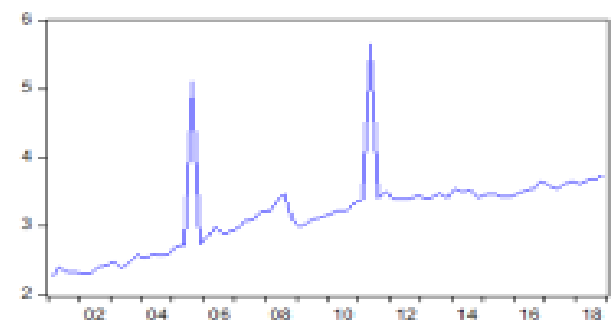

LMS

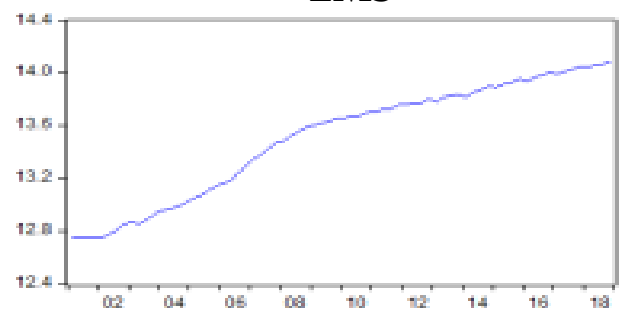

LIPI

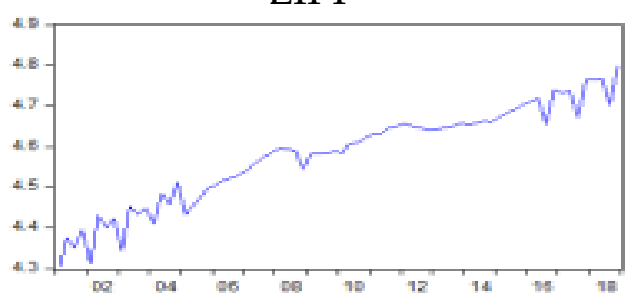

\subsection{Correlations between variables}

According to the results in Table 3 (Correlation between variables), it seems that there is a very significant correlation (with probability $<5 \%$ ) between the different variables. The results confirmed that all the variables are auto-correlated.

Table 3: Variables' correlation

\begin{tabular}{|c|c|c|c|c|c|}
\hline Variables & LREER & LMPI & LCPI & LMS & LIPI \\
\hline $\begin{array}{l}\text { LTREER } \\
\text { p-value }\end{array}$ & $\begin{array}{l}1 \\
-\end{array}$ & & & & \\
\hline $\begin{array}{l}\text { LMPI } \\
\text { p-value }\end{array}$ & $\begin{array}{c}-0.711973 \\
0.0000 \\
\end{array}$ & $\begin{array}{l}1 \\
- \\
\end{array}$ & & & \\
\hline $\begin{array}{l}\text { LCPI } \\
p \text {-value }\end{array}$ & $\begin{array}{c}-0.804872 \\
0.0000\end{array}$ & $\begin{array}{c}0.692954 \\
0.0000\end{array}$ & $\begin{array}{l}1 \\
- \\
\end{array}$ & & \\
\hline $\begin{array}{l}\text { LMS } \\
\text { p-value }\end{array}$ & $\begin{array}{c}-0.830473 \\
0.0000 \\
\end{array}$ & $\begin{array}{c}0.721214 \\
0.0000 \\
\end{array}$ & $\begin{array}{c}0.992896 \\
0.0000 \\
\end{array}$ & $\begin{array}{l}1 \\
- \\
\end{array}$ & \\
\hline $\begin{array}{l}\text { LIPI } \\
p \text {-value }\end{array}$ & $\begin{array}{c}-0.810172 \\
0.0000\end{array}$ & $\begin{array}{c}0.709605 \\
0.0000\end{array}$ & $\begin{array}{c}0.971337 \\
0.0000\end{array}$ & $\begin{array}{l}0.970700 \\
0.0000\end{array}$ & $\begin{array}{l}1 \\
-\end{array}$ \\
\hline
\end{tabular}




\subsection{The unit root tests}

To test the stationarity ${ }^{\mathrm{iii}}$ of time series, several tests are available: Augmented DickeyFuller (ADF) test, Phillips-Perron (PP) test, Ng-Perron test, Kwiatkowski, Phillips, Schmidt and Shin (KPSS) test, etc. These tests are commonly used.

Referring to the different stationarity tests Table 4 (unit root test of variables), the series are non-stationary in level and stationary in first difference. Since the series are integrated in order 1, vector auto-regressive model (VAR) can be applied.

The variables which initially were non-stationary at level, after the first differentiation, they become stationary. To estimate the SVAR model, the time series will be used in their stationary state.

Table 4: Unit root tests

\begin{tabular}{|l|c|c|c|c|c|c|c|}
\hline Variables & $\begin{array}{c}\text { ADF } \\
\text { (level) }\end{array}$ & $\begin{array}{c}\text { P P } \\
\text { (level) }\end{array}$ & $\begin{array}{c}\text { KPSS } \\
\text { (level) }\end{array}$ & $\begin{array}{c}\text { ADF } \\
\text { (diff 1) }\end{array}$ & $\begin{array}{c}\text { P P } \\
\text { (diff 1) }\end{array}$ & $\begin{array}{c}\text { KPSS } \\
\text { (diff 1) }\end{array}$ & Stationarity \\
\hline LREER & -0.8842 & -0.8842 & 0.8771 & -9.0397 & -9.0868 & 0.2610 & stationary in integration \\
(p-value) & $(0.3296)$ & $(0.3296)$ & $(0.0000)$ & $(0.0000)$ & $(0.0000)$ & $(0.3126)$ & order 1 \\
\hline LMPI & 0.3304 & 0.3625 & 0.9334 & -9.6590 & -27.7392 & 0.3446 & stationary in integration \\
(p-value) & $(0.7781)$ & $(0.7867)$ & $(0.0000)$ & $(0.0000)$ & $(0.0000)$ & $(0.6115)$ & order 1 \\
\hline LCPI & -0.8736 & -1.5777 & 1.1199 & -9.2985 & -9.7425 & 0.2396 & stationary in integration \\
(p-value) & $(0.7911)$ & $(0.4886)$ & $(0.0000)$ & $(0.0000)$ & $(0.0000)$ & $(0.5118)$ & order 1 \\
\hline LMS & -1.9484 & -0.0832 & 0.2609 & -3.3198 & -8.6681 & 0.2399 & stationary in integration \\
(p-value) & $(0.6182)$ & $(0.9943)$ & $(0.000)$ & 0.0419 & $(0.0000)$ & $(0.3681)$ & order 1 \\
\hline LIP I & -1.718 & -1.4721 & 1.1099 & -13.2788 & -30.4938 & 0.2072 & stationary in integration \\
(p-value) & $(0.4177)$ & $(0.5419)$ & $(0.000)$ & $(0.0001)$ & $(0.0001)$ & $(0.3742)$ & order 1 \\
\hline
\end{tabular}

\subsection{Lag determination, VAR estimation and diagnostic}

\subsubsection{Determination of optimal lag of VAR}

As with any dynamic model, information criteria (Akaike (AIC), Schwarz's (SIC) and Hannan and Quinn's (HQ)) are used to determine the optimal lag ( $\mathrm{p}^{*}$ or $\mathrm{q}^{*}$ ). An optimal lag is the one where the estimated model provides the minimum value of the information criteria, the (table 5) (VAR lag order selection criteria) show that the optimal lag which minimizes statistics AIC, SC and HQ is 1, this lag correspond to the order of estimated VAR: soit, VAR (1).

Table 5: VAR Lag order selection criteria

\begin{tabular}{|c|c|c|c|c|c|c|}
\hline Lag & LogL & LR & FPE & AIC & SC & HQ \\
\hline 0 & 467.7705 & NA & $5.59 \mathrm{e}-13$ & -14.02335 & -13.85747 & -13.95780 \\
\hline 1 & $\mathbf{7 6 8 . 2 4 8 7}$ & $\mathbf{5 4 6 . 3 2 4 0}$ & $\mathbf{1 . 3 3 e - 1 6}$ & $\mathbf{- 2 2 . 3 7 1 1 7}$ & $\mathbf{- 2 1 . 3 7 5 8 7 ^ { * }}$ & $\mathbf{- 2 1 . 9 7 7 8 8 ^ { * }}$ \\
\hline 2 & 787.9094 & 32.76793 & $1.58 \mathrm{e}-16$ & -22.20938 & -20.38466 & -21.48835 \\
\hline 3 & 801.1094 & 19.99995 & $2.34 \mathrm{e}-16$ & -21.85180 & -19.19767 & -20.80303 \\
\hline 4 & 840.3079 & 53.45247 & $1.62 \mathrm{e}-16$ & -22.28206 & -18.79582 & -20.90554 \\
\hline 5 & 877.1166 & $44.61658^{*}$ & $1.27 \mathrm{e}-16$ & -22.63990 & -18.32694 & -20.93564 \\
\hline 6 & 911.6228 & 36.59749 & $1.13 \mathrm{e}-16^{*}$ & $-22.92796^{*}$ & -17.78559 & -20.89597 \\
\hline
\end{tabular}

iii absence of unit root 


\subsubsection{VAR estimation and its diagnostic}

The estimates coefficients of VAR model are shown in the Table 6 (VAR estimation coefficients). The coefficients and their probabilities are also shown in (Table 6) below:

Table 6: Estimated VAR coefficients

\begin{tabular}{|l|c|c|c|c|c|}
\hline & D(LREER) & D(LMPI) & D(LCPI) & D(LMS) & D(LTPT) \\
\hline & 0.004003 & -8.664928 & -0.095758 & 0289052 & 0.155698 \\
\hline & $(0.13395)$ & $(5.68550)$ & $(0.07975)$ & $(0.21276)$ & -0.34416 \\
\hline & {$[0.02989]$} & {$[-1.52404]$} & {$[-1.20079]$} & {$[1.35856]$} & {$[0.45240]$} \\
\hline & 0.003017 & -0.551667 & 0.002056 & -0.000773 & $-7.335 \mathrm{E}-0.5$ \\
\hline & $(0.00264)$ & $(0.11190)$ & $(0.00157)$ & $(0.00419)$ & -0.00677 \\
\hline & {$[1.14450]$} & {$[-4.93020]$} & {$[1.30990]$} & {$[-0.18461]$} & {$[-0.10082]$} \\
\hline D(LCPI(-1)) & -0.006205 & -0.386353 & 0.030267 & -0.024064 & -0.573154 \\
\hline & $(0.24287)$ & $(10.3083)$ & $(0.14459)$ & $(0.38576)$ & -0.624 \\
\hline & {$[-0.02555]$} & {$[-0.03748]$} & {$[0.20933]$} & {$[-0.06238]$} & {$[-0.91852]$} \\
\hline D(LMS(-1)) & 0.049756 & -1.344593 & -0.004457 & 0.036514 & -0147183 \\
\hline & $(0.07890)$ & $(3.34874)$ & $(0.04697)$ & $(0.12532)$ & -0.20271 \\
\hline & {$[0.63065]$} & {$[-0.40152]$} & {$[-0.09490]$} & {$[0.29137]$} & {$[-0.72608]$} \\
\hline D(LIPI(-1)) & -0.041726 & 0.153229 & -0.034480 & 0.027339 & -0.652374 \\
\hline & $(0.03826)$ & $(1.62378)$ & $(0.02278)$ & $(0.06077)$ & -0.09829 \\
\hline & {$[-1.09069]$} & {$[0.09437]$} & {$[-1.51391]$} & {$[0.44992]$} & -6. \\
\hline & -0.001497 & 0.044703 & 0.003949 & 0.018788 & $0.01463708]$ \\
\hline C & $(0.00214)$ & $(0.09064)$ & $(000127)$ & $(0.00339)$ & -0.00549 \\
\hline & {$[-0.70080]$} & {$[0.49320]$} & {$[3.10650]$} & {$[5.53896]$} & {$[2.73010]$} \\
\hline & 0.150148 & 0.291159 & 0.092008 & 0.041083 & 0.438746 \\
\hline R-squared & -0.024060 & 0.235781 & 0021071 & -0.033832 & 0.394899 \\
\hline Adj. R-squared & 0.008679 & 15.63650 & 0.003076 & 0.021898 & 0.057296 \\
\hline Sum sq. resids & 0.011645 & 0.494288 & 0.006933 & 0.018497 & 0.029921 \\
\hline S.E. equation & 0.675778 & 5.257655 & 1.297039 & 0.548399 & 10.00609 \\
\hline F-statistic & 215.5095 & -46.86464 & 251.8134 & 183.1199 & 149.4549 \\
\hline Log likelihood & -5.985987 & 1.510418 & -7.023241 & -5.060569 & -4.098711 \\
\hline Akaike AIC & -5.793259 & 1.703146 & -6.830513 & -4867841 & -3.905983 \\
\hline Schwarz SC & -0.000766 & 0.018908 & 0.003956 & 0.019142 & 0.006065 \\
\hline Mean dependent & 0.011508 & 0.565420 & 0.007007 & 0018192 & 0.038464 \\
\hline S.D. dependent & & & & & \\
\hline
\end{tabular}

In the estimation output, it is seen that the estimated VAR has passed post estimationstests, except for heteroskedasticity and normality tests. The results of diagnostic test of the estimated model are shown in Table 7 (results of diagnostic tests of the estimated model), The null hypothesis is accepted for the tests of autocorrelation and heteroskedasticity (Table 7). The estimated model is therefore statistically valid.

Table 7: VAR estimated diagnostic

\begin{tabular}{|l|c|c|}
\hline Hypothesis test & Tests & Values and probabilities \\
\hline Autocorrelation & Breusch-Godfrey & 52.43931 (prob:0.0700) \\
\hline Normality & Jarque-Bera & 391.2536 (prob:0.0000) \\
\hline Heteroskedasticity & Breusch-Pagan-Godfrey & 319.3845 (prob.0.2113) \\
\hline
\end{tabular}




\section{Structure and identification of the SVAR model}

\subsection{SVAR Specification}

The analysis is carried out using a structural VAR model that belongs to Bernanke (1986) and Sims (1986) to examine the inter-relationships between the exchange rate and prices in Morocco over the period 2000-2018. The structural VAR model is based on economic theory rather than the decomposition of Cholesky. This model is used in order to recover structural innovations from the residuals of a reduced form of VAR (This VAR model has been criticized as being devoid of any economic content). The SVAR model is represented as follows:

To simplify or generalize the structural or primitive and reduced equations can be written as follow:

$$
\begin{aligned}
& \mathrm{AX}_{\mathrm{t}}=\mathrm{C}(\mathrm{L}) \mathrm{X}_{\mathrm{t}}+\beta \varepsilon_{\mathrm{t}} \\
& \mathrm{X}_{\mathrm{t}}=\mathrm{A}^{-1} \mathrm{C}(\mathrm{L}) \mathrm{X}_{\mathrm{t}}+\mathrm{A}^{-1} \beta \varepsilon_{\mathrm{t}} \\
& \text { If, } \mathrm{e}_{\mathrm{t}}=\mathrm{A}^{-1} \beta \varepsilon_{\mathrm{t}} \text { then, } \mathrm{X}_{\mathrm{t}}=\mathrm{A}^{-1} \mathrm{C}(\mathrm{L}) \mathrm{X}_{\mathrm{t}}+\mathrm{e}_{\mathrm{t}}
\end{aligned}
$$

Where:

- C(.): the matrix of model parameters;

- A: the matrix of structural coefficients (instantaneous effects);

- $\beta$ : a diagonal matrix of shocks;

- L: the lag;

$-\varepsilon t$ : the errors or shocks (primitive form);

- $e_{\mathrm{t}}$ : the residuals (reduced form).

Before estimating the SVAR, the description of shocks shown in Table 1 above is important to understand the effects of shocks on variables.

In SVAR modeling, we proceed by structural factorization which consists in modifying the elements of the matrix $\mathrm{A}$, which stops being identity ${ }^{\mathrm{iv}}$, in order to take into account, the structural effects of the variables. The elements of matrix " $\mathrm{A}$ " are not randomly modified, the economic theory and observation of facts are used, also, modifying the A matrix exposes the SVAR to the risk of under identification, which will make very difficult to estimate the reduced form. To overcome the identification problem, restrictions must be applied to the SVAR.

\subsection{Constrained SVAR estimate (short-term restrictions)}

The minimum number of restrictions to be imposed on the SVAR model is identified at 10. This will allow to orthogonalize the residuals of the model. To identify the SVAR, it should be taken into account the results of Granger's causality test. Indeed, the following restrictions (i.e. 10 restrictions) will be proposed.

\footnotetext{
iv In a simple VAR, the square and symmetrical matrix A is composed of " 1 " on the diagonal and "0" all around, to reflect the absence of simultaneous or structural effects between variables.
} 
The money supply (MS) is exogenous, so it is not influenced by any variables (REER, MPI, CPI and IPI) in the short term, reacting only to idiosyncratic shocks (its own shocks). This affirmation leads to cancel the following parameters: $\mathrm{a}_{4 ; 1}, \mathrm{a}_{4 ; 2}, \mathrm{a} 4 ; 3$ and $\mathrm{a} 4 ; 5$.

In the short term, the price level does not justify exchange rate fluctuations. Thus, we cancel the coefficients: $\mathrm{a}_{1 ; 3}$ and $\mathrm{a} 1 ; 5$.

According to Ca'Zorzi et al. (2007), price variables are affected simultaneously by all variables in the model. Following the price-setting chain, MPIs precede industrial production prices, then come consumer prices taking into account the contemporary impact of MPI shocks on production prices and the contemporary impact of production price shocks on consumer prices. But the opposite influence is not valid, which allows to cancel the coefficients $\mathrm{a}_{2 ; 3,} \mathrm{a}_{2 ; 4}, \mathrm{a}_{2} ; 5, \mathrm{a} ; 3$ and $\mathrm{a} 3 ; 5$.

The exchange rate reacts instantaneously only to innovations triggered by the MPI, which allows to cancel the coefficients $\mathrm{a}_{1 ; 3}$ and $\mathrm{a}_{1 ; 5}$. While imports and the industrial production index do not react instantaneously to innovations caused by the exchange rate or the money supply, these results can be translated by the nullity of the coefficients $\mathrm{a}_{2 ; 1}$ and $\mathrm{a}_{2 ; 4} \mathrm{a}_{5 ; 1}$ and $\mathrm{a}_{5} ; 4$.

Taking these restrictions into account, the constrained A matrix is written as follows:

$$
\mathrm{A}(\mathrm{L})=\left(\begin{array}{ccccc}
\mathrm{a}_{1.1} & \mathrm{a}_{1.2} & \mathrm{a}_{1.3} & \mathrm{a}_{1.4} & \mathrm{a}_{1.5} \\
\mathrm{a}_{2.1} & \mathrm{a}_{2.2} & \mathrm{a}_{2.3} & \mathrm{a}_{2.4} & \mathrm{a}_{2.5} \\
\mathrm{a}_{3.1} & \mathrm{a}_{3.2} & \mathrm{a}_{3.3} & \mathrm{a}_{3.4} & \mathrm{a}_{3.5} \\
\mathrm{a}_{4.1} & \mathrm{a}_{4.2} & \mathrm{a}_{4.3} & \mathrm{a}_{4.4} & \mathrm{a}_{4.5} \\
\mathrm{a}_{5.1} & \mathrm{a}_{5.2} & \mathrm{a}_{5.3} & \mathrm{a}_{5.4} & \mathrm{a}_{5.5}
\end{array}\right)=\left(\begin{array}{ccccc}
1 & \mathrm{a}_{1.2} & 0 & \mathrm{a}_{1.4} & 0 \\
0 & 1 & 0 & 0 & 0 \\
0 & \mathrm{a}_{3.2} & 1 & 0 & 0 \\
0 & 0 & 0 & 1 & 0 \\
0 & \mathrm{a}_{5.2} & \mathrm{a}_{5.3} & 0 & 1
\end{array}\right)
$$

We know that:

$e_{\mathrm{t}}=\mathrm{A}^{-1} \varepsilon_{\mathrm{t}}$

$\mathrm{A} e_{\mathrm{t}}=\mathrm{AA}^{-1} \varepsilon_{\mathrm{t}}$

In matrix form, the expression Aet $=\beta \varepsilon t$ is written by taking into account restrictions that orthogonalize the residues:

$\left(\begin{array}{ccccc}1 & \mathrm{a}_{1.2} & 0 & \mathrm{a}_{1.4} & 0 \\ 0 & 1 & 0 & 0 & 0 \\ 0 & \mathrm{a}_{3.2} & 1 & 0 & 0 \\ 0 & 0 & 0 & 1 & 0 \\ 0 & \mathrm{a}_{5.2} & \mathrm{a}_{5.3} & 0 & 1\end{array}\right)\left(\begin{array}{c}e \mathrm{REER} \\ e \mathrm{MPI} \\ e \mathrm{CPI} \\ e \mathrm{MS}_{\mathrm{t}} \\ e \mathrm{IPI}_{\mathrm{t}}\end{array}\right)=\left(\begin{array}{lllll}\mathrm{b}_{1.1} & 0 & 0 & 0 & 0 \\ 0 & \mathrm{~b}_{2.2} & 0 & 0 & 0 \\ 0 & 0 & \mathrm{~b}_{3.3} & 0 & 0 \\ 0 & 0 & 0 & \mathrm{~b}_{4.4} & 0 \\ 0 & 0 & 0 & 0 & \mathrm{~b}_{5.5}\end{array}\right)\left(\begin{array}{c}\varepsilon \mathrm{REER} \\ \varepsilon \mathrm{MPI}_{\mathrm{t}} \\ \varepsilon \mathrm{CPI} \\ \varepsilon \mathrm{MS}_{\mathrm{t}} \\ \varepsilon \mathrm{IPI}_{\mathrm{t}}\end{array}\right)$ 


\begin{tabular}{|l|c|c|c|c|c|}
\hline \multicolumn{7}{c}{ Table 8: Short term restrictions } \\
\hline Variables & REER & MPI & CPI & MS & IPI \\
\hline REER $\boldsymbol{t}_{\boldsymbol{t}}$ & 1.000000 & 0.004934 & 0.000000 & 0.036262 & 0.000000 \\
\hline $\boldsymbol{M P I}_{\mathbf{t}}$ & 0.000000 & 1.000000 & 0.000000 & 0.000000 & 0.000000 \\
\hline $\boldsymbol{C P \boldsymbol { I } _ { t }}$ & 0.000000 & 0.003863 & 1.000000 & 0.000000 & 0.000000 \\
\hline $\boldsymbol{M S}_{\boldsymbol{t}}$ & 0.000000 & 0.000000 & 0.000000 & 1.000000 & 0.000000 \\
\hline $\boldsymbol{I P I}_{\boldsymbol{t}}$ & 0.000000 & -0.001827 & -0.215575 & 0.000000 & 1.000000 \\
\hline
\end{tabular}

In order to verify the significance of the identification restriction, it is necessary to perform the likelihood ratio test. The LR test gives significant results so that our identification restriction is accepted $(\chi 2()=22.29616$; $\mathrm{p}$ - value $=0.0005)$. It can be verified that the level of significance $p$ is less than $0.01(1 \%)$, therefore, we can simply accept the restrictions imposed in the identification of the $A(L)$ matrix, and the result obtained seems to indicate that the model is robust.

\subsection{Estimation of the constrained SVAR (long term restrictions)}

To determine the long-term effects of a permanent shock on one of the endogenous variables in the model, the equation is written as follow:

$\left(\mathrm{I}-\mathrm{A}^{-1} \mathrm{C}(\mathrm{L})\right) \mathrm{Xt}=\mathrm{A}^{-1} \beta \varepsilon \mathrm{t}$

$X t=\left(I-A^{-1} C(L)\right)^{-1} A^{-1} \beta \varepsilon t$

$F=\left(I-A^{-1} C(L)\right)^{-1} A^{-1} \beta$. The " $F^{\prime \prime}$ matrix includes the effects of long-term cumulative shocks between variables; and its null values reflect the absence of effect between the concerned variables. The important work consists, then, in estimating a structural VAR model which its matrix form is as follow:

$\mathrm{X}_{\mathrm{t}}=\mathrm{F}(\mathrm{L}) \varepsilon_{\mathrm{t}}$

With F (L) is the matrix of coefficients $\left(f_{i j}\right)$ associated with its lags. It presents the long-term restrictions that will be established on the basis of the Blanchard-Quah (1989) identification. We note that i represent the variable undergoing the shocks, and $\mathrm{j}$ : the nature of the shock. For the system of chosen variables, we identify the different shocks from the following matrix $F(L)$ :

$$
\mathrm{F}(\mathrm{L})=\left(\begin{array}{ccccc}
\mathrm{f}_{1.1} & \mathrm{f}_{1.2} & \mathrm{f}_{1.3} & \mathrm{f}_{1.4} & \mathrm{f}_{1.5} \\
\mathrm{f}_{2.1} & \mathrm{f}_{2.2} & \mathrm{f}_{2.3} & \mathrm{f}_{2.4} & \mathrm{f}_{2.5} \\
\mathrm{f}_{3.1} & \mathrm{f}_{3.2} & \mathrm{f}_{3.3} & \mathrm{f}_{3.4} & \mathrm{f}_{4.4} \\
\mathrm{f}_{4.1} & \mathrm{f}_{4.2} & \mathrm{f}_{4.3} & \mathrm{f}_{4.4} & \mathrm{f}_{4.5} \\
\mathrm{f}_{5.1} & \mathrm{f}_{5.2} & \mathrm{f}_{5.3} & \mathrm{f}_{5.4} & \mathrm{f}_{5.5}
\end{array}\right)
$$


$\mathrm{X}_{\mathrm{t}}$ : represents the vector of variables of the proposed VAR system. It is written as follow: $X_{t}=\left(R_{E E R}, M I_{t}, C P I_{t}, M S_{t}, I P I_{t}\right)$;

$\varepsilon t$ : is the vector of structural shocks. It is presented as follows:

$\varepsilon_{\mathrm{t}}=\left(\varepsilon \mathrm{REER}_{\mathrm{t}} ; \varepsilon \mathrm{IPM} ; \varepsilon \mathrm{IPC}_{\mathrm{t}} ; \varepsilon \mathrm{MS} \mathrm{t} ; \varepsilon \mathrm{IPI} \mathrm{t}\right)$.

To estimate an SVAR model and obtain the impulse response functions (IRF) and variance decompositions (VD), it is necessary to use the structural shocks $\varepsilon_{\mathrm{t}}$ and not the prediction errors $e_{\text {t. }}$. These innovations are a linear combination of structural shocks $\varepsilon_{t}$. Thus, the idea of the structural decomposition is to take the observed values of $e_{\mathrm{t}}$ from an empirical VAR and restrict the system so as to recover $\varepsilon$ t. However, additional identification assumptions will be required.

Bernanke-Sims has introduced an identification method based on restrictions on the properties at long-term RFI. The minimum number of " $\mathrm{K}$ " restrictions to be imposed on a system (VAR or SVAR) to identify it is given by the formula:

$K=\frac{n(n-1)}{2}$

Where: $\mathrm{n}$ is the number of endogenous variables in the system or number of equations.

To be able to make restrictions on the matrix F, we use the Bernanke-Sims decomposition in which the order of the variables is not important as Cholesky's decomposition. However, in order to perform the LR test proposed by Sims, the variables in the model are classified into two groups:

The non-strategic vector includes the variables $\mathrm{IPI}_{\mathrm{t}}, \mathrm{MPI} \mathrm{I}_{t}$ and $\mathrm{CPI}$ and the strategic vector includes the variables REER $\mathrm{t}_{\mathrm{t}}$ and $\mathrm{MS} \mathrm{S}_{\mathrm{t}}$. To identify the impact of policy variables in the structural VAR, we assume that the vector of non-policy variables cannot react instantaneously to the vector of policy variables. Furthermore, as Sims and Zha (1998) a non-recursive identification system allows simultaneous interaction between the exchange rate and the money supply. Consequently, we must first make restrictions on the F matrix. We suggest the following restrictions for the matrix F:

$$
F(L)=\left(\begin{array}{ccccc}
f_{1.1} & f_{1.2} & f_{1.3} & f_{1.4} & 0 \\
f_{2.1} & f_{2.2} & 0 & 0 & 0 \\
f_{3.1} & f_{3.2} & f_{3.3} & 0 & 0 \\
f_{4.1} & 0 & 0 & f_{4.4} & 0 \\
f_{5.1} & f_{5.2} & f_{5.3} & 0 & f_{5.5}
\end{array}\right)
$$

According to Ca'Zorzi et al. (2007), price variables are affected simultaneously by all variables in the model. By reference to the pricing chain fixation, the MPIs precede the production prices. Then come consumer prices, taking into account the contemporary impact of shocks transmitted to PPIs on producer prices and the contemporary impact of 
producer price shocks on consumer prices and not vice versa (McCarthy, 2000, Ca'Zorzi et al., 2007; Bhundia, 2002), which allows us to cancel the coefficients $f_{2.3}, f_{2.4}, f_{2.5}, f_{3.4}$ and $f_{3.5}$.

We assume that the vector of non-strategic variables (MPI; IPI $; \mathrm{CPI}_{t}$ ) can react to the variables (REER $\left.{ }_{t}\right)$ and don't react to the variable $M S_{t}$.

The exchange rate reacts only to innovations triggered by the variables MPI $\mathrm{t}$ and $\mathrm{MS}_{\mathrm{t}}$, which allow us to cancel the coefficients $\mathrm{f}_{1.2}$ and $\mathrm{f}_{1.4}$, whereas Imports and the industrial production index do not react to innovations in the money supply; This assertion results in the annulation of the coefficients $\mathrm{f}_{2.4}$ and $\mathrm{f}_{5.4}$

Sek and Kapsalyamova (2008) supported the hypothesis that the exchange rate is simultaneously affected by supply and demand shocks, but probably affected by the IPI, which allows us to cancel the coefficient $\mathrm{f}_{1.5}$.

Finally, the fourth line can be interpreted as the response of monetary policy to exchange rate fluctuations. This is reflected in the annulation of the coefficients $\mathrm{f}_{4.2,}, \mathrm{f}_{4.3}$ and $\mathrm{f}_{4.5}$. The restrictions in the long term are grouped in table 10 (long term restrictions).

Table 9: Long term restrictions

\begin{tabular}{|l|c|c|c|c|c|}
\hline Variables & REER & MPI & CPI & MS & IPI \\
\hline$R E E R_{t}$ & 0.0011527 & 0.019463 & -0.000445 & -0.006470 & 0.000000 \\
\hline$M P I_{t}$ & -0.109297 & 0.018261 & 0.000000 & 0.000000 & 0.000000 \\
\hline$C P I_{t}$ & 0.002033 & ${ }^{*} 0.001477$ & 0.005903 & 0.000000 & 0.000000 \\
\hline$M S_{t}$ & 0.315389 & 0.000000 & 0.000000 & 0.013176 & 0.000000 \\
\hline$I P I_{t}$ & 0.006207 & 0.000952 & -0.001743 & 0.000000 & 0.017931 \\
\hline
\end{tabular}

The LR test gives significant results so that the identification restriction is accepted ( $\mathrm{p}$ value $=0.04260$ ). We can verify that the level of significance $p$ is less than 0.05 . Therefore, we cannot reject the assumption that the restrictions are restrictive. Furthermore, we can accept the restrictions imposed in the identification of the matrix $F(L)$, and the result suggests that the model is robust. The SVAR is now correctly identified and can therefore be estimated. The model's IRFs are used to evaluate the pass-through of the exchange rate on the different prices.

Figure 2: Graphical representation of impulse responses

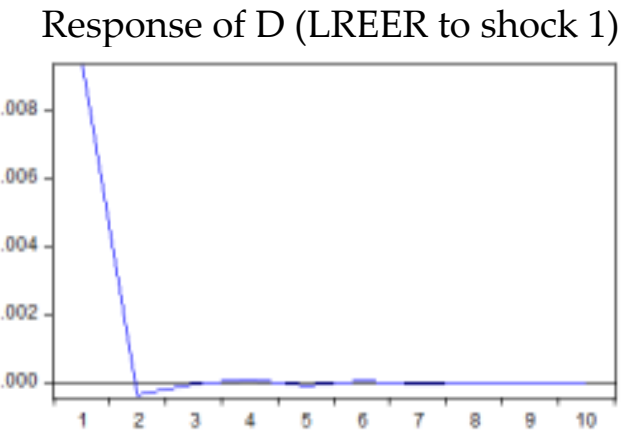

Response of D(LCPI ) to shock
Response of D (LMPI to shock 1)

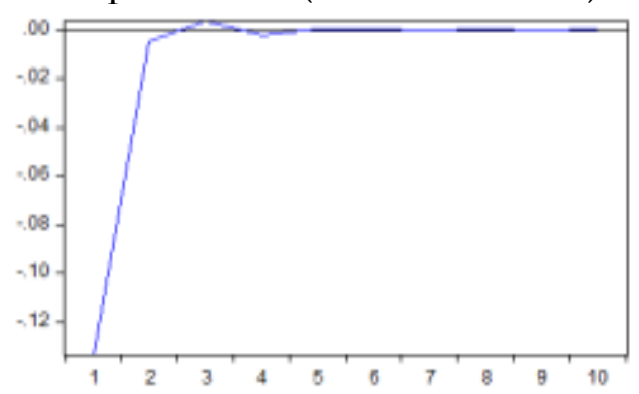

Response of D(LIPI) to shock 1 

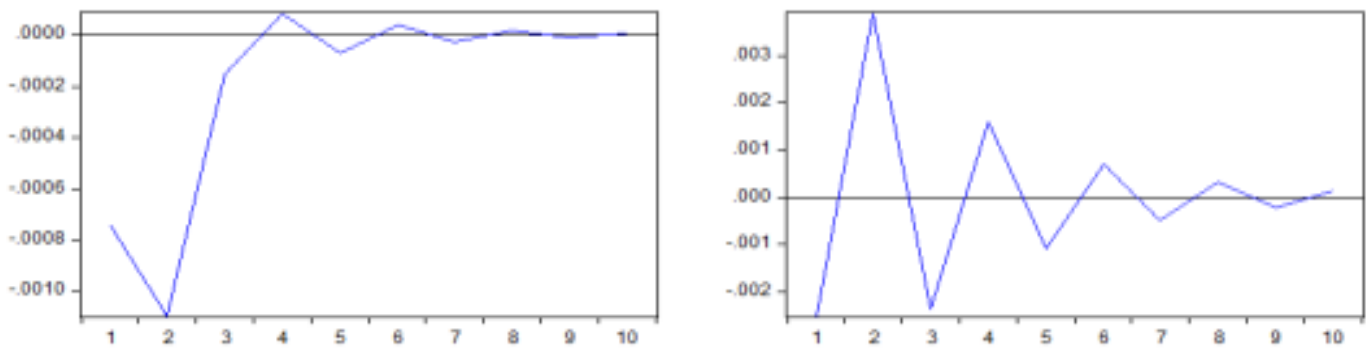

We look forward to capture, graphically, the impact of "structural or fundamental shocks" on the endogenous variables of the system (estimated SVAR model). To consider only long-term price dynamics, these shocks are presented as follows:

Table 10: Shocks and degree of impact

\begin{tabular}{|l|c|c|}
\hline ER innovations & Time & magnitude \\
\hline Response (+) $R E E R_{t}$ & 5 & Important \\
\hline Response (-) MPIt & 4 & Important \\
\hline Response (-) CPI & 9 & Important \\
\hline Response (-/+) IPIt & 9 & Important \\
\hline
\end{tabular}

\subsection{Pass through to exchange rate pass through calculation}

The response functions allow estimating the pass-through of the REER to price indices. Consequently, we have opted for the calculation of the responses of different variables to a shock of the REER. The pass-through (PT) with SVAR (p) model is calculated from the ratio of the p-order cumulative impulse functions according to the following formula:

$\mathrm{PT}=\frac{\sum_{\mathrm{i}=1}^{\mathrm{p}} \varnothing \mathrm{i}}{\sum_{\mathrm{i}=1}^{\mathrm{p}}(\mathrm{REER})}$

Where,

$\varphi$ i: Cumulative impulse responses of the price index to a shock on the REER after $p$ quarters.

$\varphi($ REER): Cumulative impulse responses of the REER to a shock on the REER after $p$ quarters.

Table 11 shows the cumulative impulse functions as well as the "Pass through" during the ten periods following the shock which matched with a period 1 .

The negative sign of the values indicates an opposite sense of variations. the MPI reacts to the decline following the positive exchange rate shock and reaches its maximum in the 10th quarter after the impact of the shock which is (-0.30). This result confirms that the pass-through to importations price is limited and incomplete; it may be due to the intervention of Government and Monetary Authorities which play a great role in adjustment of importation prices.

The CPI indicates an incomplete pass-through $(<1)$, which exceeds 0.5 after the 8 th quarter. The sense of variation of the CPI even if it remains limited, but confirms the 
hypothesis that a shock to exchange rates will tend to make products more expensive in domestic market.

The IPI decreased throughout the 10 periods and reached its maximum of $0.17 \%$ following a $1 \%$ increase in the variation of the REER. The percentage of variation of the IPI due to exchange rate shocks remains weak. This can be explained by the fact that domestic firms adjust their prices in response to external shocks to the exchange rate, or their imported intermediary products entering in the finished manufactured products represent a marginal part.

\section{Results and Discussion}

The results found through this work will be compared to others belonging to different contexts:

Anh et al. (2018), in a study concerning the pass-through to consumer prices in Vietnam, by using the SVAR approach found an incomplete pass through from exchange rate to aggregated inflation that occurs within two quarters, the magnitude of the passthrough varies across sub-components, essentially in housing and construction materials as well as food and food stuff. Given the instantaneous response of inflation to exchange rate shocks and the considerable differences in the magnitude of transmission across inflation sub-indices, exchange rate movements highlight the complexity of the transmission mechanism. The result established by this study corroborates with the one we found in Moroccan context. In fact, the pass-through of the exchange rate to domestic prices, in Morocco, remains like Vietnam incomplete and in the majority of cases (lower than 0.5 ). We can affirm that in both countries a large and incomplete exchange rate passthrough to domestic prices can affect budget planning, savings, and profits of firms and households. These results imply that the cost of currency devaluation affects society as a whole in terms of welfare.

Another study carried out by Vo Duc (2018) concerning exchange Rate Passthrough in ASEAN Countries: An Application of the SVAR Model, the essential finding is that here is an incomplete pass-through of the ERPT to domestic prices in all countries in the sample during the research period, although producer prices are more affected than consumer prices. Second, exchange rate shocks have an immediate effect on domestic prices, and the exchange rate shocks affect immediately the domestic prices, the result which is found presents contradictions with our results especially that in Morocco the pass through of the exchange rate to the industrial production prices has a tendency to fall and occur in the opposite sense of a positive shock affecting the exchange rate even if it remains always incomplete. In Egyptian context, a study done by Omneia et al. (2018) using a SVAR approach, this paper estimated the exchange rate pass-through to domestic prices for Egypt over the period 2003-2015. The IRFs for the basic model show that exchange rate pass-through to PMI is evident and positive in the first three months. The IRFs for the basic model show that exchange rate pass-through to PMI is evident and positive in the first three months. The impact of exchange rate movements and PMIs on the PPI and CPI is quite large but incomplete and slow. The same finding in this paper is 
confirmed in Egyptian context, the explanation to this incompleteness of the pass through is due to fact that the CPI in Egypt and Morocco is composed of large number of subsidized commodities and goods with an administrated prices, this can prevent the transmission of exchange rate shocks. For the CPI, its positive response to exchange rate shocks is larger than its response to PMI shocks, implying that the indirect transmission channel (i.e. exchange rate changes on producer prices) is stronger than the direct channel (i.eMPI changes on producer prices) in Egypt. The VD (variance decomposition) results from the baseline SVAR model suggest that changes in the exchange rate affect locally produced semi-finished goods and that, as a result, producer price levels should increase and, consequently, those of consumer prices. These results support the IRF findings in the both contexts.

\section{Conclusions}

The fact that the CPI in Morocco is composed of a relatively large number of subsidized commodities and price-administered goods, as well as the authorities' behavior in manipulating prices, the transmission of exchange rate shocks to CPI stay relatively weak. The results showed that the shocks associated to fluctuations of exchange rate generates a mitigate impacts on the different prices indices. This effect on consumer price index is limited because of the intervention of government that use the compensation fund in order to balance commodity prices, especially since this indicator, in its main composition, constitutes subsidized products, while the effect on the IPI and the MPI leads to an important pass through and raises the price of the imported products and the non-subsidized products used in the industrial chain.

\section{Acknowledgements}

In this section, I would like to express my sincere thanks to everyone who contributed to the completion of this work, especially to those who helped me gain access to the different sources of data, those who helped me with the linguistic revision of this work. My thanks are addressed to my teachers for their inexhaustible support.

\section{Conflict of Interest Statement}

The authors declare no conflicts of interests.

\section{About the Authors}

El Amri Youness, PhD student at National School of Commerce and Management of Fez, RSMEF lab, Research and Study Laboratory in Management, Entrepreneurship and Finance, USMBA University of Fez, Morocco. elamriyouness@gmail.com.

Abdelhamid El Bouhadi, professor of higher education at National School of Commerce and Management of Fez, RSMEF lab, Research and Study Laboratory in Management, Entrepreneurship and Finance, USMBA University of Fez, Morocco elbouhadihamid@yahoo.fr. 
Mimoun Benali, professor of higher education at National School of Commerce and Management of Fez, RSMEF lab, Research and Study Laboratory in Management, Entrepreneurship and Finance, USMBA University of Fez, Morocco, mimoun.benali@usmba.ac.ma.

\section{References}

Anh The V., Chi Minh H. (2018). Understanding The Exchange Rate Pass-Through Consumer Prices in Vietnam: The SVAR Approach, International Journal of Emerging Markets, Vol. 15 No. 5, 2020 pp. 971-989 (C) Emerald Publishing Limited 1746-8809.

Beirne, J. and Bijsterbosch, M. (2009). Exchange Rate Pass-Through in Central and Eastern European Member States, Working paper series no. 1120, ECB, December.

Benigno, P. and Faia, E. (2016). Globalization, Pass-Through, And Inflation Dynamics, International Journal of Central Banking, Vol. 12 No. 4, pp. 263-306.

Ben S. Bernanke (1986). Alternative Explanations of the Money-Income Correlation, NBER Working Paper No. w1842.

Blanchard, O. and Quah, D. (1989). The Dynamic Effects of Aggregate Demand and Supply Disturbances, American Economic Review, Vol. 79 No. 4, pp. 655-673.

Blanchard, O. and Perotti, R. (1999). An Empirical Characterization of the Dynamic Effects of Changes in Government Spending and Taxes on Output, The Quarterly Journal of Economics, Volume 117, Issue 4, November 2002, Pages 1329-1368.

Bhundia, A., (2002). An Empirical Investigation Exchange Rate Pass-Through in South Africa International Monetary Fund (IMF), IMF Working Paper No. 02/165.

Forbes, K., Hjortsoe, I. and Nenova, T. (2018). The Shocks Matter: Improving Our Estimates of Exchange Rate Pass-Through, Journal of International Economics, Vol. 114, pp. 255-275.

Ca'Zorzi, M., Hahn, E. and Sanchez, M. (2007). Exchange Rate Pass-through in Emerging Markets. European Central Bank Working Paper Series No. 739.

Choudhri, E. U. and Hakura, D. S. (2006). Exchange Rate Pass-Through to Domestic Prices: Does The Inflationary Environment Matter?, Journal of International Money and Finance 25, 614-639

Coulibaly, D. and Kempf, H. (2010). Does Inflation Targeting Decrease Exchange Rate Pass-Through in Emerging Countries? CES WP 2010-49.

Darvas, Z. (2001). Exchange Rate Pass-Through and Real Exchange Rate in EU Candidate Countries, National Bank of Hungary, Discussion Paper 10, Economic Research Centre of the Deutsche, Bundes Bank, Bruegel.

Dornbusch R. (1976). Proceedings of a Conference on Flexible Exchange Rates and Stabilization Policy , The Scandinavian Journal of Economics. Vol. 78, No. 2 (Jun., 1976), pp. 255-275 (21 pages)

Gagnon, J. E., Ihrig, J. (2004). Monetary policy and the exchange rate pass-through. International Journal of Finance \& Economics, 9, 315-338. 
Ghosh, A., Rajan, R. S. (2009). Exchange Rate Pass-Through in Korea and Thailand: Trends and determinants. Japan and the World Economy, 21, 55-70.

Gust, C., Leduc, S. and Vigfusson, R. (2010). Trade Integration, Competition, and The Decline in Exchange-Rate Pass-Through, Journal of Monetary Economics, Vol. 57 No. 3, pp. 309-324.

Hájek, J., Horváth, R. (2016). The Spillover Effect of Euro Area on Central and Southeastern European Economies: A Global VAR Approach. Open Econ Rev 27, 359-385 (2016).

Helmy O., Fayed M, Hussien F. (2017). Exchange Rate Pass-Through to Inflation in Egypt: A Structural VAR Approach, Review of Economics and Political Science Vol. 3 No. 2, 2018pp. 2-19 Emerald Publishing Limited 2631-3561.

Hendry, D. F. (1980). Predictive Failure and Econometrics modelling In MacroEconomics: The Transactions Demand for Money. Modemng The Economy, London: Heinemann Educational Books.

Ivohasina Fizara Razafimahefa (2012). Exchange Rate Pass-Through in Sub-Saharan African Economies and Its Determinants, June 2012.

Jiang, J., and D. Kim (2013). Exchange Rate Pass-Through to Inflation in China. Economic Modelling 33: 900-912.

Jeffrey A. Frankel, David C. Parsley \& Shang-Jin Wei (2005). Slow Passthrough Around the World: A New Import for Developing Countries? National Bureau of Economic Research, Working Paper 11199 .

Krugman, P. (1989). Exchange Rate Instability: The Delinking of Exchange Rates from Reality, MIT Press, Cambridge, MA.

Lopez-Villavicencio, A. and Mignon, V. (2016). Exchange Rate Pass-Through in Emerging Countries: Do the Inflation Environment, Monetary Policy Regime and Institutional Quality Matter? CEPII WP 2016-07.

McCarthy, J. (2000). Pass-Through of Exchange Rates and Import Prices to Domestic Inflation in Some Industrialized Economies, Staff Report No. 111, Federal Reserve Bank of New York.

Rachidi L., Assandadi, Y. (2016). Analyse Empirique De La Réaction Des Prix Domestiques Aux Variations Du Taux De Change: Cas Du Maroc. Revue Marocaine de Gestion et d’Economie, N6, Janvier- Juin 2016.

Razafimahefa, I. F. (2012). Exchange Rate Pass-Through in Sub-Saharan African Economies and Its Determinants, IMF Working Paper 141, June, IMF, Washington, DC.

Sek, Siok Kun and Kapsalyamova, Zhanna (2008). Exchange Rate Pass-Through and Volatility: Impacts on Domestic Prices in Four Asian Countries. Munich Personal RePEc Archive.

Sims, C. A. (1986). Are forecasting models usable for policy analysis?, Federal Reserve Bank of Minneapolis Quarterly Review Winter, Vol. 10 No. 1

Sims and Tao Zha (1998). Bayesian Methods for Dynamic Multivariate Model, International Economic Review, Vol 39, 4 November 1993. 
Christopher Sims and Tao Zha (1998). Bayesian Methods for Dynamic Multivariate Models, International Economic Review, 1998, vol. 39, issue 4, 949-68.

Soto, C. and Selaive, J. (2003). Openness And Imperfect Pass-Through: Implications for The Monetary Policy, Working Papers 216, Central Bank of Chile.

Steel, D. and King, A. (2004). Exchange Rate Pass-Through: The Role of Regime Changes, International Review of Applied Economics, Vol. 18 No. 3, pp. 301-322.

Takhtamanova, Y. (2008). Understanding Changes in Exchange Rate Pass-Through, Working paper 13, Federal Reserve Bank of San-Francisco.

Taylor, J. B. (2000). Low Inflation, Pass-Through, and the Pricing Power of Firms. European. Economic Review, 44, 1389-1408. https://doi.org/10.1016/s00142921(00)00037-4

Vo, A. T., Le, Q. T. T., Nguyen, P. V., Ho, C. M. and Vo, D. H. (2018). Exchange Rate PassThrough in ASEAN Countries: An Application of The SVAR Model, Emerging Markets Finance and Trade, pp. 1-14.

Vo, Duck (2018). Exchange Rate Pass-through in ASEAN Countries: An Application of the SVAR Model, Business and Economics Research Group, Munich Personal RePEc Archive, MPRA Paper No. 103283

Frankel, J. A., D. C. Parsley, and S.-J. Wei. (2005). Slow Pass-Through Around the World: A New Import for Developing Countries. NBER Working Paper 11199, National Bureau of Economic Research, Cambridge, MA. 

applied to their work. Under the terms of this license, no permission is required from the author(s) or publisher for members of the community to copy, distribute, transmit or adapt the article content, providing a proper, prominent and unambiguous attribution to the authors in a manner that makes clear that the materials are being reused under permission of a Creative Commons License. Views, opinions and conclusions expressed in this research article are views, opinions and conclusions of the author(s). Open Access Publishing Group and European Journal of Economic and Financial Research shall not be responsible or answerable for any loss, damage or liability caused in relation to/arising out of conflict of interests, copyright violations and inappropriate or inaccurate use of any kind content related or integrated on the research work. All the published works are meeting the Open Access Publishing requirements and can be freely accessed, shared, modified, distributed and used in educational, commercial and non-commercial purposes under a Creative Commons Attribution 4.0 International License (CC BY 4.0). 